\title{
Endophytic microflora from Ficus carica L. leaves - isolation, characterization and potential for application
}

\author{
Emiliya Lozanova $^{1}$, Elena Savova ${ }^{1}$,Vasilka Lateva ${ }^{1}$, and Tsvetanka Teneva-Angelova ${ }^{2 *}$ \\ ${ }^{1}$ Department of Analytical Chemistry and Physical Chemistry, University of Food Technologies, Plovdiv, Bulgaria \\ ${ }^{2}$ Laboratory of Cell Biosystems, Department of Biotechnology, The Stephan Angeloff Institute of Microbiology, Bulgarian Academy \\ of Sciences, Plovdiv, Bulgaria
}

\begin{abstract}
Fig leaves (Ficus carica L.) are widely used in traditional medicine as a remedy or for prevention of many health problems (lowering blood sugar and triglyceride levels, cardiovascular diseases, etc.). The aim of the research was isolation of endophytic microflora, its characterization and proving its potential for future application. Two endophytic bacteria Streptococcus sp. Fcll and Kocuria rhizophila Fcl20 were isolated from the fig leaves and characterized. Using HPLC method was also determined the polyphenolic profile of aqueous-alcoholic extract $(70 \%(\mathrm{v} / \mathrm{v})$ ethanol) and microwave-assisted aqueous extract of fig leaves, for the purpose of phytochemical characterization of the plant, for subsequent study of the endophyte-plant relationship. The main found phenolic acids and flavonoids in extracts were: $(+)$-catechin, vanillic acid, syringic acid, (-)-epicatechin, ferulic acid, salicylic acid, rosmarinic acid, rutin.
\end{abstract}

\section{INTRODUCTION}

Endophytic bacteria are plant beneficial bacteria that growth into plants. They colonize inside plant tissues and can contribute for plant growth under normal and stress conditions, getting protection and nutrition substances from the host plant. The endophytes can benefit host plants directly by improving plant nutrient uptake and by adjusting growth and stress related phytohormones; as well as indirectly, improving plant health by targeting pests and pathogens by producing functional metabolites $[1,2]$. The endophytes are used among different activities such as antimicrobial and antifungal, plants stimulation, pigments producing, biocontrol agents, and others. Many endophytes are producing metabolites that are inhibiting human pathogens and parasites [3, 4].

Ficus carica L., known as fig, belongs to the Moraceae family, genus Ficus. This genus consists of around 800 species of woody plants, epiphytes and bushes in the tropical and subtropical regions around the world [5]. Ficus carica (fruit, leaf, roots) has been widely used in traditional medicine as a remedy or as prevention of many health problems. It is used to treat respiratory, gastrointestinal and cardiovascular disorders. It has been extensively studied for its therapeutic value, healthpromoting properties and medicinal uses $[6,7,8]$. It was reported that Ficus carica leaves possess antimicrobial, antioxidant, anticancer, hepatoprotective, antiinflammatory, antidiabetic activities and many others [9, $10,11,12,13,14]$. All those activities are due to the high content of biologically active substances in the leaves of figs. From $F$. carica leaves have been isolated phenolic acids, flavonoids, organic acids, coumarins, phytosterols, triterpenoids, fatty acids, volatile constituents $[14,15,16$, $17,18,19]$.

Data for isolation of endophytic bacteria from Ficus carica L. in scientific literature are scarce.

Representatives of Klebsiella oxytoca, Pseudomonas sp. and Pantoea sp. were isolated from fig crops (Ficus carica var. Brown Turkey) in Costa Rica [20].

This study has been an evaluation of presence of endophytic bacterial microflora in Ficus carica L. The main aim of this research has been isolation, characterization and identification of endophytic bacteria and proving their resistance against Ficus carica leaves extract (bioactive compounds) and their future application potential.

\section{MATERIALS AND METHODS}

\subsection{Collection of plant material}

Fig leaves samples were collected in the month of May 2021 from the town of Simeonovgrad, Haskovo region, Southern Bulgaria. Plant samples were taken aseptically in sterile containers, and transported in cooling bag to the laboratory for subsequent analyses.

\subsection{Isolation of endophytic bacteria}

Plant material for isolation of endophytic bacteria was taken aseptically in sterile containers, and transported under refrigeration to the laboratory. Fig leaves were washed in running tap water and their surface was sterilized by $70 \%(\mathrm{v} / \mathrm{v})$ ethanol for $30 \mathrm{~s}$ followed by 
treatment with calcium hypochlorite $4 \%(\mathrm{w} / \mathrm{v})$ for $10 \mathrm{~min}$ and washed with sterile distilled water. The leaves were sterile grounded in a mortar, then 10 -fold dilutions with saline solution were conducted, followed by transferring on Nutrient agar medium (HiMedia, India) at $37^{\circ} \mathrm{C}$, for 25 days, until obtaining single bacterial colonies. These single colonies were purified by multiple transfers on fresh NA medium and incubated at $37^{\circ} \mathrm{C}$ for $2-5$ days.

\subsection{Characterization and identification of endophytic bacteria}

Characterization of endophytic bacterial isolates included microscopic characterization of the morphology of cells (Olympus CX23, Olympus Corporation, Japan) and colonies (size, shape and color) (CETI Digi Steddy II, Medline Scientific, Chalgrove, Oxfordshire, UK) as well as subsequent Gram staining and catalase test.

The endophytic bacteria were genetically identified using 16S rDNA sequence analysis, which analysis was conducted at "Macrogen Europe Laboratory", The Netherlands. The two isolates were grown in Nutrient broth at $37^{\circ} \mathrm{C}$ for $48 \mathrm{~h}$ and sent in glycerol for subsequent analysis. The partial sequencing of the 16S rRNA gene was performed with two universal primers $785 \mathrm{~F}$ and 907R. The whole sequence of the 16S rRNA gene was obtained using the BioEdit software program. The obtained sequences were compared with those in the National Center for Biotechnology Information (NCBI) database, using BLAST (http://www.ncbi.nlm.nih.gov/ BLAST/).

\subsection{Preparation of plant extracts}

The fig leaves were washed with tap water and then with sterile distilled water. Then they were dried at room temperature, powdered and used for preparation of extracts. Aqueous-alcoholic extract $(70 \%(\mathrm{v} / \mathrm{v})$ ethanol) and microwave-assisted aqueous extract were prepared.

The aqueous-alcoholic extract: the dried and powdered leaves were mixed with $70 \%(\mathrm{v} / \mathrm{v})$ ethanol (1:20) by stirring for $24 \mathrm{~h}$ at room temperature. The extract was filtrated through filter paper and then concentrated in a vacuum evaporator. The microwaveassisted aqueous extract: the dried and powered leaves were extracted with water (1:20) using a labor microwave oven. Six cycles were alternated: $30 \mathrm{~s}$ at $750 \mathrm{~W}$, followed by $10 \mathrm{~min}$ at room temperature. The extract was filtrated though filter paper. Both extracts were storage at $-20^{\circ} \mathrm{C}$ for further study.

\subsection{HPLC analyses}

The presence of phenolic acids and flavonoids were determined using HPLC method described by Mladenova et al. [21].

Concentration of each compound was presented as $\mu \mathrm{g}$ compound per g dry extract (DE).

\subsection{Effect of Ficus carica leaves extracts against endophytic bacteria growth}

The agar well diffusion method was used to examine the effect of Ficus carica leaves extracts against endophytic bacteria (isolated from them) growth [22]. Some modifications were made: NA medium was used for cultivation of the tested microorganisms. The ethanolic extract was dissolved in 10\% dimethyl sulfoxide (DMSO) (Merck Millipore, Darmstadt, Germany) (200 mg/ml, 150 $\mathrm{mg} / \mathrm{ml}, 100 \mathrm{mg} / \mathrm{ml}, 10 \mathrm{mg} / \mathrm{ml})$, and aqueous extract $(1.7 \%$ dry weight) was used directly. The $10 \%$ DMSO and water were used as negative control. Cefotaxime (MIP Pharma, Blieskastel, Germany) and mupirocin (HiMedia, India) were used as positive control. The effect of $F$. carica leaves extracts against endophytic bacteria was detected by measuring of diameters of inhibition zone (with the diameter of well) (mm). Data shows the average values of three replicates and the standard deviation.

\section{RESULTS AND DISCUSSION}

\subsection{Isolation, characterization and identification of endophytic bacteria from Ficus carica L. leaves}

After subsequent multiple transfers and growth in Nutrient agar and Nutrient broth, two endophytic bacterial isolates were isolated from Ficus carica L. leaves (Isolate Fcl1 and Isolate Fcl20). They were Gram-positive and catalase-negative. The cells of isolate Fcll were a cocci shaped, arranged in pairs, short and long chains and size around $0.8-1.0 \mu \mathrm{m}$. Isolate Fcl1 had white, shiny, circular, raised colonies with undulate margins, size $1.0-1.2 \mathrm{~mm}$ in diameter. The cells of isolate Fcl20 were also cocci shaped, arranged in pairs, tetrads, irregular clusters, and size around $1.2-1.3 \mu \mathrm{m}$. Isolate Fcl20 had yellow, smooth, circular, convex colonies with entire margins, and size $1.2-1.5 \mathrm{~mm}$ in diameter.

Identification of the isolates was carried out using $16 \mathrm{~S}$ rDNA sequence analysis. After BLAST in NCBI database, obtained sequences were compared with reference sequences. The isolate Fcll showed maximum percentage of identity with Streptococcus sp. and similar lower percentage of identity with different species from Streptococcus genus. For this reason, the isolate Fcl1 was identified to genus level. The isolate Fcl20 showed $100 \%$ identity with Kocuria rhizophila.

The nucleotide sequences of endophytic bacteria were deposited in NCBI GenBank under the following accession numbers: Streptococcus sp. Fcl1 - accession number OK018347 and Kocuria rhizophila Fcl20 accession number OK018346.

Plant species provides unique conditions for growth of different endophytic bacteria. Similar to our results, Streptococcus species were identified in maple trees [23] and banana leaves [24] using molecular-genetic methods for identification of bacteria. Kocuria rhizophila has been isolated from stems of sugarcane plant [25] and from Oxalis corniculata [26]. 


\subsection{HPLC analyses}

The results for phenolic acids and flavonoids content in Ficus carica L. leave extracts showed variety of these biological active components (Table 1). It was observed a wider range of phenolic compounds in the extracts. The ethanolic extract contained (+)-catechin, vanillic acid, syringic acid, (-)-epicatechin, ferulic acid, salicylic acid, rosmarinic acid, rutin, as well as p-coumaric acid, hesperidin, quercetin and kaempferol in minimal concentration. In comparison with ethanolic extract, the aqueous extract contained also chlorogenic acid, protocatechuic acid and caffeic acid, in minimal concentration.

Table 1. HPLC quantification of polyphenolic compounds in ethanolic and aqueous extracts from Ficus carica leaves.

\begin{tabular}{|l|c|c|}
\hline Compound & $\begin{array}{c}\mathbf{7 0 \%} \text { Ethanolic } \\
\text { extract, } \boldsymbol{\mu g} / \mathbf{g} \text { DE }\end{array}$ & $\begin{array}{c}\text { Aqueous } \\
\text { extract, } \boldsymbol{\mu g} / \mathbf{g} \text { DE }\end{array}$ \\
\hline Gallic acid & nd & nd \\
\hline $\begin{array}{l}\text { Protocatechuic } \\
\text { acid }\end{array}$ & nd & trace \\
\hline (+)-Catechin & 323.3 & 185.4 \\
\hline Chlorogenic acid & nd & 57.6 \\
\hline Vanillic acid & 313 & 57.4 \\
\hline Caffeic acid & nd & trace \\
\hline Syringic acid & 250.4 & 30.7 \\
\hline (-)-Epicatechin & 977.5 & 132.2 \\
\hline p-Coumaric acid & trace & 44.3 \\
\hline Ferulic acid & 622.7 & 4559.7 \\
\hline Salicylic acid & 1015.6 & 2169.7 \\
\hline Rosmarinic acid & 1242.6 & 205.0 \\
\hline Rutin & 2627.9 & 583.6 \\
\hline Hesperidin & trace & 83.0 \\
\hline Quercetin & trace & 94.8 \\
\hline Kaempferol & trace & 51.5 \\
\hline
\end{tabular}

n d - not detected

Ficus carica $\mathrm{L}$. leaves contain compounds from the group of polyphenols [14, 27]. The presence of phenolic acids was established in $F$. carica $\mathrm{L}$. leaves aqueous extracts [28].

\subsection{Effect of Ficus carica leaves extracts against endophytic bacteria growth}

By examination of the inhibitory effect of Ficus carica leaves extracts (ethanolic and aqueous), it was found that endophytic bacteria were resistant against high extracts concentration. Kocuria rhizophila Fcl20 was not susceptible against all tested plant extract concentrations (Table 2). Inhibition of Streptococcus sp. Fcll was observed at a concentration of ethanolic extract 200 $\mathrm{mg} / \mathrm{ml}$, but it was also resistant to the aqueous extract, as Kocuria rhizophila Fcl20. Cefotaxime $(50 \mu \mathrm{g} / \mathrm{ml})$ inhibited in larger scale the growth of Kocuria rhizophila Fcl20 (48.0 $\pm 2.5 \mathrm{~mm})$ in comparison to Streptococcus sp. Fcl1 $(38.0 \pm 2.5 \mathrm{~mm})$. At Mupirocin it was established reverse trend, concentration of $50 \mu \mathrm{g} / \mathrm{ml}$ inhibited the growth of Streptococcus sp. Fcl1 $(30.0 \pm 2.0 \mathrm{~mm})$, and it did not influent the growth of Kocuria rhizophila Fcl20 (Table 2). The water and 10\% DMSO did not inhibit the growth of studied strains.

The available scientific information, with regard to studies of effect of Ficus carica leaves extracts against endophytic bacteria growth (isolated from the same plant) is scarce. Most scientific teams examined the antimicrobial activity of Ficus carica extracts against testmicroorganisms, for example Staphylococcus aureus, Pseudomonas aeruginosa, Pseudomonas fluorescens, Acinetobacter baumannii, Salmonella enteritidis, Bacillus subtilis, Bacillus cereus, Escherichia coli, Klebsiella pneumonia etc. [10, 14, 29].

\section{CONCLUSIONS}

The results of this study showed presence of endophytic bacterial microflora in Ficus carica L. Two strains Streptococcus sp. Fcl1 and Kocuria rhizophila Fcl20 were isolated from leaves and subsequent characterized and genetically identified. It was established the resistance of endophytic bacteria against the plant (from which they are isolated) and its biologically active compounds. That proved the ability of endophytic bacteria for growth with plant extract (high concentration of biological active compounds) and confirmed their potential for future application. They can be used as elicitors to trigger secondary metabolism and improve the yield of the plant secondary metabolites, which are mainly related to the protection of plants from various pathogens, as well as their resistance to various stress factors.

\section{REFERENCES}

1. I. Afzal, Z.K. Shinwari, S. Sikandar, S. Shahza, Microbiol. Res. 221, 36-49 (2019)

2. R.X. Tan, W.X. Zou, Nat. Prod. Rep. 18, 448-459 (2001)

3. S. Fendrihan, Ch.-E. Pop, Rom. Biotechnol. Lett. 26, 2700-2706 (2021)

4. E. Martinez-Klimova, K. Rodriguez-Peña, S. Sanchez, Biochem. Pharmacol. 134, 1-17 (2017)

5. D. Singh, B. Singh, R. K. Goel, J. Ethnopharm. 134, 565-583 (2011)

6. S. B. Badgujar, V. V. Patel, A. H. Bandivdekar, R. T. Mahajan, Pharm. Biol. 52, 1487-1503 (2014)

7. M. F. Khairuddin, H. Haron, H. M. Yahya, N. A. H. C. Malek, J. Agric. Sci. 9, 41 (2017)

8. S. Mawa, K. Husain, I. Jantan, Evid.-Based Compl. Med. 3, 974256 (2013) 
Table 2. Effect of Ficus carica leaves extracts against endophytic bacteria growth.

\begin{tabular}{|l|c|c|c|c|l|l|l|}
\hline \multirow{2}{*}{ Microorganisms } & \multicolumn{7}{|c|}{ Inhibition Zone (diameter, mm) } \\
\cline { 2 - 8 } & \multicolumn{2}{|c|}{} & $\begin{array}{l}\text { aqueous } \\
\text { extract }\end{array}$ & $\begin{array}{l}\text { cefotaxime, } \\
\boldsymbol{\mu g} / \mathbf{m l}\end{array}$ & $\begin{array}{l}\text { mupirocin, } \\
\boldsymbol{\mu g} / \mathbf{m l}\end{array}$ \\
\cline { 2 - 8 } & $\mathbf{2 0 0}$ & $\mathbf{1 5 0}$ & $\mathbf{1 0 0}$ & $\mathbf{1 0}$ & & $\mathbf{5 0}$ & $\mathbf{5 0}$ \\
\hline Streptococcus sp. Fcl1 & $13.0 \pm 1.0$ & - & - & - & - & $38.0 \pm 2.5$ & $30.0 \pm 2.0$ \\
\hline $\begin{array}{l}\text { Kocuria rhizophila } \\
\text { Fcl20 }\end{array}$ & - & - & - & - & - & $48.0 \pm 2.5$ & - \\
\hline
\end{tabular}

(-) - resistant, without zone of inhibition

9. G. A. Askari, A. Kahouadji, K. Khedid, L. Ouaffak, M. Mousaddak, R. Charof, Z. Mennane, J. Mater. Environ. Sci. 4, 33-38 (2013)

10. O. Belguith-Hadriche, S. Ammar, M. del M. Contreras, H. Fetoui, A. Segura-Carretero, A. El Feki, M. Bouaziz, Biomed. Pharmacother. 89, 185-193 (2017)

11. S. Hira, M. Gulfraz, S. S. M. Naqvi, R. U. Qureshi, H. Gul, Trop. J. Pharm. Res. 20, 113-119 (2021)

12. M.-R. Jeong, H.-Y. Kim, J.-D. Cha, J. Bacteriol. Virol., 39, 97-102 (2009)

13. S. Mahmoudi, K. Mustapha, A. Benkhaled, K. Benamirouche, I. Baiti, Asian Pac. J. Trop. Biomed. 6, 239-245 (2016)

14. M. I. Barolo, N. R. Mostacero, S. N. López, Food Chem. 164, 119-127 (2014)

15.Z. Li, Y. Yang, M. Liu, C. Zhang, J. Shao, X. Hou, J. Tian, Q. Cui, Biomed. Pharmacother. 137, 111393 (2021)

16. A. P. Oliveira, L. R. Silva, P. G. de Pinho, A. GilIzquierdo, P. B. Valentão, B. M. Silva, J. A. Pereira, P. Andrade, Food Chem. 123, 548-557 (2010)

17. R. R. Solana, A. Romano, Modern fruit industry (IntechOpen, London, 2019)

18. L. Yao, Y. Mo, D. Chen, T. Feng, S. Song, H. Wang, M. Sun, LWT - Food Sci. Technol. 150, 111982 (2021)

19. L. Alvarado-Marchena, A. Schmidt-Durán, C. Alvarado-Ulloa, R. Chacón-Cerdas, D. Flores-Mora, Am. J. Agric. Biol. Sci. D. Singh, B. Singh, R. K. Goel, J Ethnopharmacol., 134, 565-83 (2011)

20. S. B. Badgujar, V. V. Patel, A. H. Bandivdekar, R. T. Mahajan, Pharm. Biol., 52, 1487-1503 (2014)

21. T. Mladenova, P. Stoyanov, P. Denev, S. Dimitrova, M. Katsarova, D. Teneva, K. Todorov, A. Bivolarska, Plants. 10, 710 (2021)

22. T. Teneva-Angelova, D. Beshkova, Sci. Bul. F. Biotech. 19, 109-116 (2015)
23. F. Wemheuer, B. Wemheuer, R. Daniel, S. Vidal, Sci. Rep. 9, 14183 (2019)

24. C. A. Souza Junior, J. Marcon, P. A. M. Andrade, J. A. Silva, M. I .F. Faraldo, M. C. Q. Verdi, A. A. M. Filho, J. L. Azevedo, J. Agric. Sci. 10, 10 (2018)

25. E. Velázquez, M. Rojas, M. J. Lorite, R. Rivas, J. L. Zurdo-Piñeiro, M. Heydrich, E. J. Bedmar, J. Basic Microbiol. 48, 118-124 (2008)

26. R. Mufti, Amna, M. Rafique, F. Haq, M. F. H. Munis, S. Masood, A. S. Mumtaz, H. J. Chaudhary, Plant Soil Environ. 34, 89-99 (2015)

27. A. P. Oliveira, P. Baptista, P. B. Andrade, F. Martins, J. A. Pereira, B. M. Silva, P. Valentão, Food Res. Int. 49, 710-719 (2012)

28. A. P. Oliveira, P. Valentão, J. A. Pereir, B. M. Silva, F. Tavares, P. B. Food Chem. Toxicol. 47, 2841-2846 (2009)

29. H. Belattar, S. Himour, A. Yahia, Rev. Mex. Cienc. Agríc. 12, 1-9 (2021) 